\title{
Laporan Harian/mingguan
}

Minggu ke IX

(Pembagian Masker)

\author{
Nama : Sukma Berlian \\ Posko : Tolo' Timur \\ Tempat Kegiatan : Kelurahan Tolo' Timur \\ Nim : 9173490210044 \\ Email: sukmagalaxy1111@gmail.com
}

1. Bentuk Kegiatan

Pembagian masker

2. Lokasi

Kelurahan Tolo Timur

3. Hari / tanggal dan waktu

Selasa 10 November 2020

4. Peserta yang di libatkan

Mahasiswa dan santri

5. Alasan di adakannya

Untuk menyelesaikan salah satu

program kerja yang kami buat

yaitu program kerja pembagian

masker di santri dan masyarakat
Kegiatan yang dilakukan bertujuan untuk kebaikan masyarakat Tolo Timur karena adanya virus covid 19 sekarang yang menyebar dengan cepat, dan dengan covid 19 kita di wajibkan untuk memakai masker untuk menghindari penyebaran

7. Deskripsi kegiatan

Dilakukan pembagian masker untuk menghindari penyebaran virus covid 19 yang merajalela di seluruh dunia

6. Tujuan dan manfaat 